\title{
AMMONIA LARGE SCALE ATMOSPHERIC DISPERSION EXPERIMENTS IN INDUSTRIAL CONFIGURATIONS
}

\author{
Rémy BOUET, Stéphane DUPLANTIER, Olivier SALVI \\ INERIS, Accidental Risks Division, BP 2, F-60550 VERNEUIL EN HALATTE, France \\ tel : +33 3445561 01, fax : +33 3445562 95, email : olivier.salvi@ ineris.fr
}

\section{Key words}

atmospheric dispersion ; large-scale experiments ; ammonia ; modelling

\begin{abstract}
A programme of large-scale experiments for atmospheric dispersion was carried out by INERIS over a period extending from December 1996 to April 1997. The objectives of the test campaign were to measure anhydrous ammonia concentrations in a range of few meters to $2 \mathrm{~km}$ from the release, in order to generate data to be used to improve 2-phase release modelling.

The discharges were released from a 6-tonne storage tank of pressurised liquid ammonia and through a discharge device with an outlet diameter of 2 inches. Fifteen trials were carried out with various release configurations corresponding to industrial situations (impinging jets on the ground and on a wall at various distances, release through a flange without seal...). The quantity of ammonia discharged from the liquid phase varied according to the tests, from 1.4 ton to 3.5 tons for durations between 7 and 14 minutes and, therefore, at flow rates between 2 and $4.5 \mathrm{~kg} / \mathrm{s}$. Approximately 200 sensors were settled downwind to measure ammonia concentrations and temperature in the plume. These tests showed that for discharges with identical flow rates the distances corresponding to the same concentration vary a lot according to the configurations. These distances tend to be reduced by the presence of obstacles or bounds that collected liquid ammonia. In the paper, the main experimental results are presented in order to enable the comparisons with numerical predictions.
\end{abstract}

\section{Introduction}

The study of the atmospheric dispersion of ammonia is of major interest for two reasons. Firstly, ammonia is a common substance, which has many uses owing to its chemical and physical properties. Secondly, ammonia is a substance that is extremely toxic, corrosive, flammable and explosive in certain conditions. It may be remembered that the failure of a 22-tonne storage tank of ammonia in Dakar on 
March 24, 1992, caused a large number of fatalities (129 dead and more than 1,100 injured) some of which were due to the toxic nature of ammonia and occurred several weeks after the accident.

In the framework of the large scale atmospheric dispersion of pollutants done before the INERIS trials, ammonia specificity was not taken into account such as : the jet formation, the aerosol generation, reactions with the moisture of the air, etc ... Several significant experimentation campaigns ware carried out by Resplandy (1969), Goldwire (1985), Wheatley (1987) and Nielsen \& Ott (1996). They all produced data related to the general aspects. These trials highlighted :

- the influence of the weather conditions ;

- the ammonia cloud behaviour which disperses as a heavy gas when it is released from a pressure tank at the ground level ;

- $\quad$ impinging jet on the ground made it possible to collect $70 \%$ of rejected.

Thanks to these trials, models were developed that are used for risk assessment and quantification of accident consequences in safety reports. But to improve the relevance of the predictions related to industrial conditions, risk assessors have data on :

- the characterisation of the release source term and diphasic jet formation in the case of releases under pressure and in particular the generation and the evolution of the aerosol ;

- $\quad$ impinging jet with more significant flow rates.

Therefore, INERIS launched in 1996 a programme of large-scale trials with the aim of improving understanding of the mechanisms of atmospheric dispersion following an accidental ammonia leak. The tests were conducted in configurations corresponding to situations which can typically be found on industrial plants (discharge outlet diameter of $50 \mathrm{~mm}$, impact on obstacles, etc...).

\section{Description of the means implemented}

\section{a) Field-test description}

Ammonia dispersion trials on a large scale were performed on the experimention field of the CEACESTA (Center of Scientific and Technical Studies of Aquitaine) near Bordeaux (FRANCE).

The site (see figure 1) has a surface of 950 hectares. It is entirely enclosed and its access is controlled permanently. The site is completely flat and is deprived of any obstacle. This ground, of approximately two kilometres of ray, has, in its middle, a square concrete flagstone of 10 meters side and approximately $15 \mathrm{~cm}$ thickness where releases have been performed.

\section{b) The release point}

In the close vicinity of the release flagstone, three tanks of ammonia, $12 \mathrm{~m}^{3}$ each one, were installed. Liquefied ammonia was stored under its saturating vapour pressure. 
During trials, only one of these tanks was connected to the release device located in the middle of the flagstone. This one was equipped with 5 thermocouples and pressure sensors, in order to follow the evolution of the conditions of pressure and temperature inside the tank during each test both in the liquid phase and in the gaseous phase.

The pressure sensor was located in the gaseous phase. This sensor is located P3 on figure 2.

The tank was also connected to a nitrogen tank making possible to pressurise it, or to maintain the constant pressure during a test, or even to purge, after a test, the pipe connecting the tank to the release device.

To perform the fifteen releases defined within the programme framework, two manual valves with a 2 inches diameter were placed on the tank : one was connected to the gaseous phase and the other one to the liquid phase. These two identical valves have not integral passage, and their real diameter is $3 / 2$ inches.

Connection between the tank and the release device was ensured by a flexible pipe of $50 \mathrm{~mm}$ diameter and $10.4 \mathrm{~m}$ length.

Lastly, the release device was composed of a pipe of 2 inches instrumented by valves, thermocouples and pressure sensors (see figure 3). Note that the axis of the point of release is $1.015 \mathrm{~m}$ above ground level.

\section{c) Atmospheric conditions measurements during trials}

For the atmospheric conditions measurements, a 10 meters height weather mast was installed at 350 meters of the outlet (reference mark $\mathrm{M}$ on figure 1). This one was composed of three cup anemometers, located at 1.5, 4 and 7 meters height, a wind vane at 7 meters and an ultrasonic anemometer at 10 meters.

A weather station was also installed beside the control unit where temperature measurements, relative humidity and solar flux were recorded. These measurements were carried out at 1.5 meter height. The frequency of acquisition of these parameters was $1 \mathrm{~Hz}$, except for the ultrasonic anemometer whose frequency was $10 \mathrm{~Hz}$.

\section{d) Ammonia sensors}

To carry out the full-scale experiments, INERIS chose to use autonomous measuring equipment to be easily moved according to the weather conditions (especially for the variations of the wind direction). Batteries ensured power supply of the sensors. For each series of measures, the data storage was carried out on EEPROM (Electrically Erasable Programmable Read Only Memory).

Thus, the measuring equipment of ammonia concentrations consisted of an electronic box on which it was possible to connect up to 4 sensors of different technologies. On the whole, 70 identical electronic boxes were used for this program. 
The electronic box has an internal clock, which starts and stops the system at specified hours. For this period, the EEPROM records the measures of the sensors at a predetermined rate. For the tests, a frequency of $0.25 \mathrm{~Hz}$ was chosen (that is to say a measure every 4 seconds), which allowed, taking into account the capacities EEPROM, to record during 8 hours.

To carry out the choice of the sensors to be installed on the 70 electronic boxes, planned releases were modelled using integral dispersion models. These results were considered as orders of magnitude and were adjusted according to the results of preliminary trials.

Thus, sensors were chosen according to the expected concentration at different points placed downwind.

Each measurement technique has a specific validity domain. The domains are orders of magnitude which can be wider according to the sensors characteristics. Finally, the sensors connected on the electronic boxes were :

- 60 catalytic sensors of pellistor type, specific to ammonia (EEV VQ 41) allowing to measure ammonia concentrations ranging between $0,1 \%$ and $15 \%$ (between $1,000 \mathrm{ppm}$ and $150,000 \mathrm{ppm}$ ). These sensors were placed in the close field (up to 200 meters of the outlet); resolution is made by step of $250 \mathrm{ppm}$ of value EEPROM 0 up to 130 , then by step of $560 \mathrm{ppm}$ of value EEPROM 131 up to 255 ;

- 50 electrochemical cells (SENSORIC NH3 3rd 1000) measuring ammonia concentrations ranging between 10 and 1,000 ppm. These sensors were laid out in the far field (from 200 meters to 1,700 meters of the outlet); resolution is made by steps of $10 \mathrm{ppm}$ up to 2,000 ppm.

It should be noted that pellistors EEV VQ41 and electrochemical cells SENSORIC NH3 3rd 1000, have been tested at INERIS in laboratory and during middle-scale releases (releases through $0,5 \mathrm{~mm}$ to $8 \mathrm{~mm}$ nozzle diameters).

In order to simplify the installation of the electronic boxes before a release, the test-field was beforehand equipped of more than 150 masts of 3 meters height. These masts could receive 4 sensors at different heights, namely $0.1,1,2$ and 3 meters. They were laid out on 7 circle arcs of $180^{\circ}$ centred on the release flagstone and whose rays were 20,50,100,200,500, 800 and 1,700 meters (see figure 1). On the first two arcs of circles located at 20 and 50 meters, 41 masts were installed, spaced each other with an angle of $4.5^{\circ}$, and on all the other arcs of circles, 21 masts were installed with $9^{\circ}$ spacing.

Moreover, 60 thermocouples (type $\mathrm{K}$, diameter $1 \mathrm{~mm}$, classifies 1 , stainless, length $5 \mathrm{~m}$ ), were used to measure mean temperature. These thermocouples were installed beside each catalytic sensor until the distance of 100 meters since the outlet, and this in particular in order to appreciate temperature variations in the jet. The resolution of the measurements is made by step of $0.3^{\circ} \mathrm{C}$, from $-40^{\circ} \mathrm{C}$ to $+40^{\circ} \mathrm{C}$.

e) Selected configurations 
The fifteen release configurations are briefly described beside each general diagram on table 1 . They are numbered of 1 with $8 \mathrm{~b}$ in the chronological order of their realisation. For each one of these configurations, the hose diameter is 2 inches $(50.8 \mathrm{~mm}$ ). Except specific indication (tests 2, 3, 4p , and $2 b)$, the circular opening is also with a 2 inches diameter and the height of the nozzle is $1.015 \mathrm{~m}$ above ground.

For all the performed tests after the $3^{\text {rd }}$, no overpressure of nitrogen was used, and the tank pressure was not maintained constant for the duration of the trial. Thus, for each test, it was observed a fall of tank pressure more or less significant according to release conditions.

\section{Main results}

Graphs on figures 4 and 5 present the conditions recorded during trial $\mathrm{n}^{\circ} 4$.

Typical evolution of the pressure conditions in the tank and in the pipe during a release is shown on figure 4.

For trial $n^{\circ} 4$, changes of the temperatures located at various heights in the tank and located in the pipe are given in figure 5 .

These figures show in particular that temperature and pressure tank decreased slowly during trial $n^{\circ} 4$.

For each of the 15 tests described previously, the atmospheric conditions are listed in table 2.

Concerning the general atmospheric conditions during tests, the following remarks could be noticed :

- From the test $\mathrm{n}^{\circ} 4$, no more rain was falling on test field. Thus, rather low relative humidity during the day were observed (only $20 \%$ for the test $\mathrm{n}^{\circ} 10$ ).

- The visible part of the plume varies much. That is mainly due to the relative humidity of the atmosphere.

Indeed, the ammonia cloud is relatively cold (approximately $-40^{\circ} \mathrm{C}$ on the axis of the release at 20 meters of the outlet) because of the presence of ammonia droplets which will take heat, in particular to the ambient air, to vaporize. The low reached temperatures make that water vapour presents on the plume trajectory condenses and forms a visible cloud until the plume is heated by dilution with ambient air.

Thus, for almost identical conditions of release (tests 4 and 11), the visible part of the plume decreased from approximately 500 meters to approximately 70 meters for a relative humidity which decreased from 82 to $24 \%$. 
- Solar flux varied much between the tests, with very low values at the beginning of the test campaign $\left(0.04 \mathrm{~kW} / \mathrm{m}^{2}\right)$ and raised during April $\left(1 \mathrm{~kW} / \mathrm{m}^{2}\right)$.

According to studied phenomena, there are various possibilities of carrying out the analysis of the concentration fluctuations which were recorded during the tests. In this paper, concentrations values which will be presented are average values of the concentrations measured on the axis of the plume (see table 3).

To obtain these values, we picked, for each step of time (of $4 \mathrm{~s}$ ), the value of maximum concentration on each of the 6 circle arcs located at 20,50, 100,200, 500 and 800 meters of the outlet. Then, we carried out on each circle arc an average of the whole of the maximum values recorded in the course of time by excluding the first and the last minute of exposure for each sensor. The beginning of sensors exposure was given by considering a time of advection of the cloud. This time was taken equal to the ratio of the distance between the arc of circle considered and the outlet by the mean velocity of the wind during the release.

\section{Discussions}

On the basis of the analysis carried out at this time, the following comments can be made. Other detailed interpretation of the results will be published in other coming papers.

- The ammonia cloud behaves like a heavy gas and no elevation of the cloud is observed.

- The temperature in the ammonia jet can fall to approximately $-70^{\circ} \mathrm{C}$.

- Solid obstacles (wall or ground) located at a few meters from the discharge point, have a considerable effect on the concentration values measured downwind the obstacle (see trials 5, 6, 7, 8, $8 \mathrm{~b}, 9)$. In this test campaign, concentrations measured downwind the obstacle were approximately half of those measured for the same discharge into a free field, which is why it is important to take into account the obstacles in the vicinity of installations when determining safety distances.

- When discharge is released towards a surface with bounds, a large amount of liquid ammonia is retained. For trials $8 \mathrm{~b}$ and 9 , more than $50 \%$ of the total discharged mass were collected in liquid form at a temperature of approximately $-60^{\circ} \mathrm{C}$.

- Liquid ammonia pool formed after impact with an obstacle does not evaporate quickly.

- Water screens (peacock tails) located across the cloud trajectory had little effect on the dispersion of ammonia cloud in the test conditions.

- Comparisons have been made between the experimental results and the results obtained using integral dispersion models. When suitable calculation hypotheses are used, especially for flow rates, these models can calculate downwind concentrations of a discharge in a free field that have the same 
order of magnitude as results obtained by experiments. For impinging releases, big differences exist between integral dispersion models and experimental results, these models don't take into account obstacles near the discharge point.

\section{Conclusions and perspectives}

The trials, carried out from a 6 ton tank of ammonia and through a discharge device an with outlet of 2 inches, led to release more than 2 tons of ammonia per trial. For all trials, sensors were located downwind of the outlet in the test field. Those trials made it possible to examine in particular the fluctuations of ammonia concentrations on circular radius located up to 1,700 meters and to determine the influence on the dispersion of the following parameters : impinging jet on a wall, impinging jet on the ground, release through a flange and presence of water curtains.

Comparisons have been made between the experimental results and the results obtained using integral dispersion models. These models can calculate downwind concentrations of a discharge in a free field that have the same order of magnitude as results obtained by experiments. However, at the present time, integral models are not able to predict downwind concentrations for the case of a discharge impacting an obstacle located a few metres away. The calculation results obtained using these models can be very different from the experimental results, unless the models are adjusted beforehand to take into account the quantity discharged into the atmosphere in the form of vapour or aerosol after the impact.

The results obtained in these tests led us to draw up a new programme in 1999 with the particular aim of developing a model which would take into account the interaction between a liquefied gas discharge and an obstacle. This model could constitute an additional module in integral models, optimising the study of specific industrial configurations.

\section{Acknowledgements}

The experimental programme was mainly funded by the Ministry in charge of Environment and by industrial sponsors : Norsk Hydro (Norway), Grande Paroisse (France), Veba Oel (Germany), SKW Piesteritz (Germany), CEA-CESTA (France) and Rhône Poulenc (France). They are sincerely acknowledged.

\section{References}

Bouet R. (1999). Ammoniac - Essais de dispersion atmosphérique à grande échelle. INERIS rapport, ref INERIS-DRA-RBo-1999-20410 (available at http://www.ineris.fr/recherches/recherches.htm)

Goldwire et al. (1985), Desert Tortoise series data report - 1983 pressurized ammonia spills, UCID 20562. 
Nielsen \& Ott (1996), Fladis Field Experiments, Final Report, RIS0-R-898(EN).

Resplandy A. (1969), Etude expérimentale des propriétés de l'ammoniac (conditionnant les mesures à prendre pour la sécurité du voisinage des stockages industriels). Chimie et Industrie - Génie chimique, Vol. 102, nº, pp. 691-702.

Wheatley C.J. (1987), Discharge of liquid ammonia to moist atmospheres - Survey of experimental data and model for estimating initial conditions for dispersion calculations, Health and Safety Executive; SRD/HSE/R 410. 


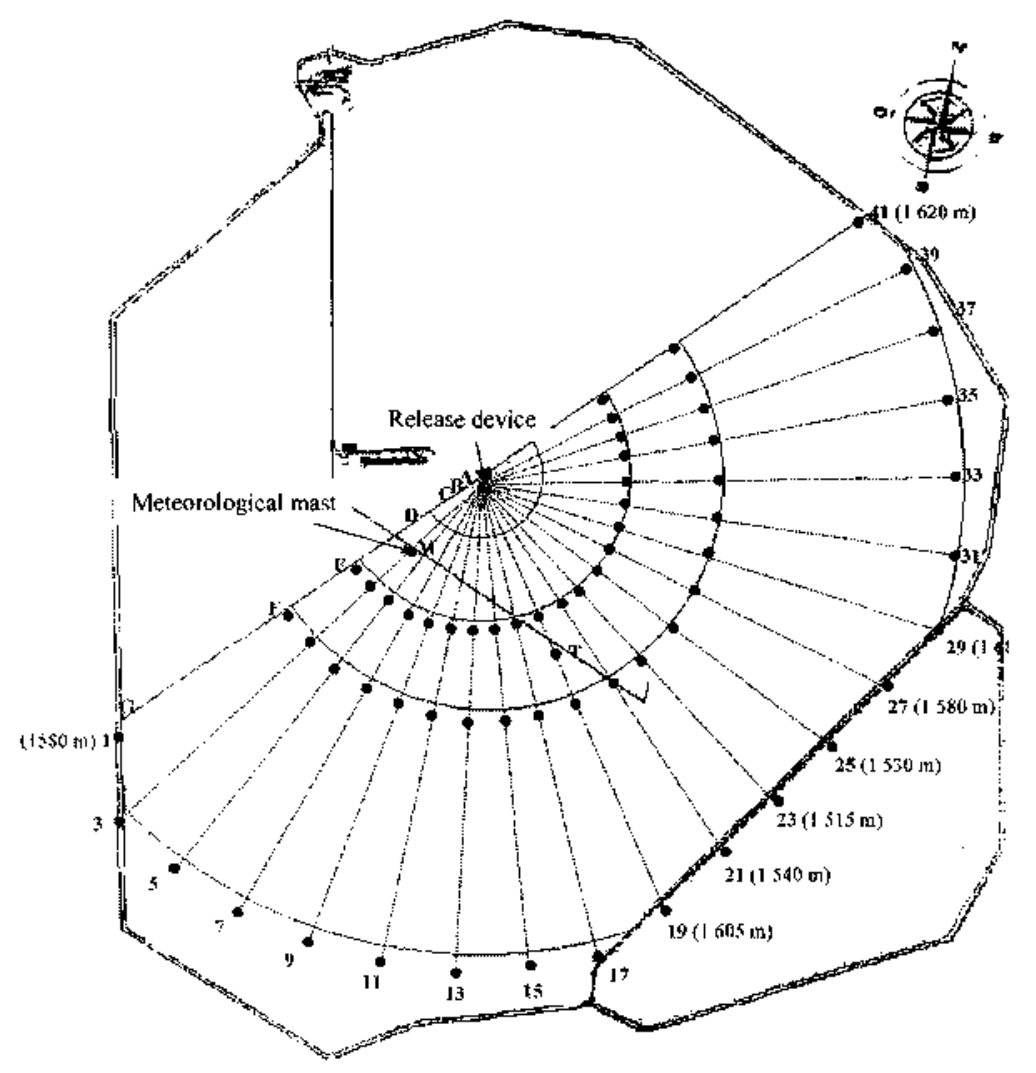

Figure $1:$ Schematic representation of the test field 


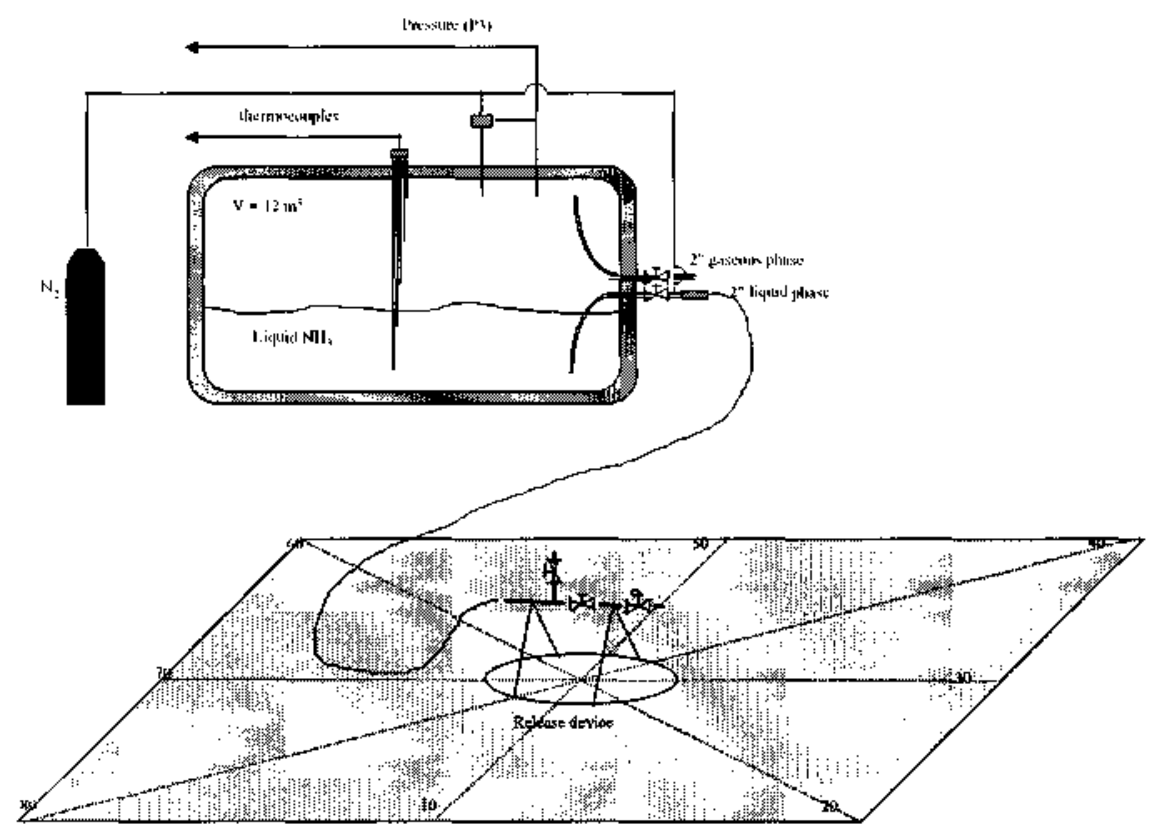

Figure 2: Schematic representation of the release devices 


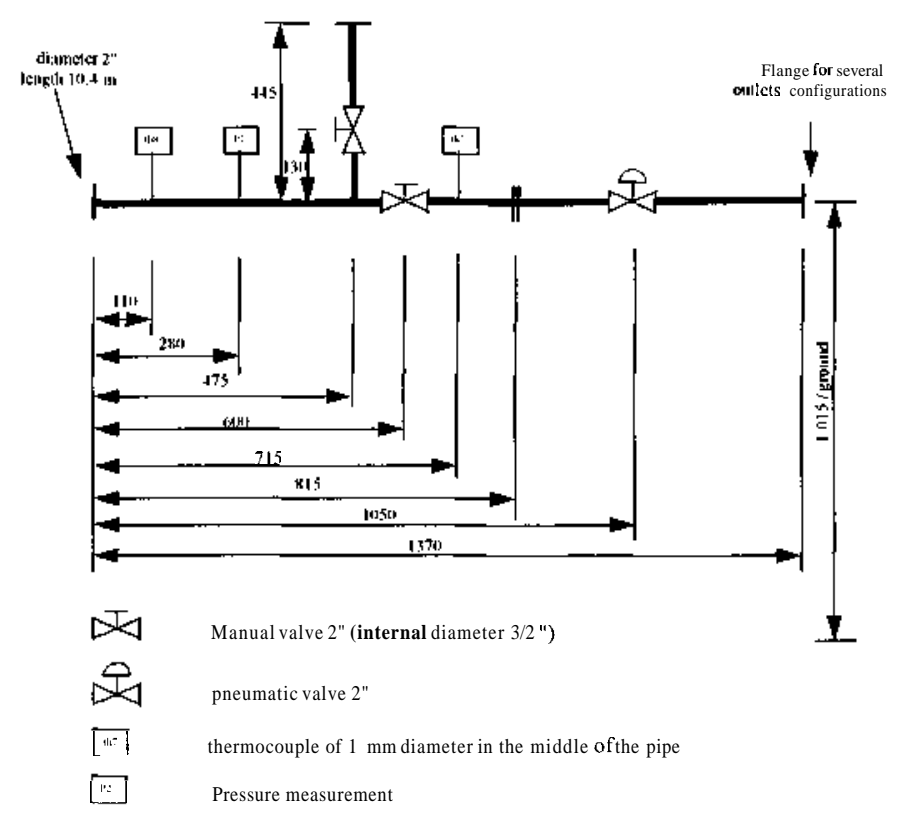

Figure 3 : Schematic representation of the release point 


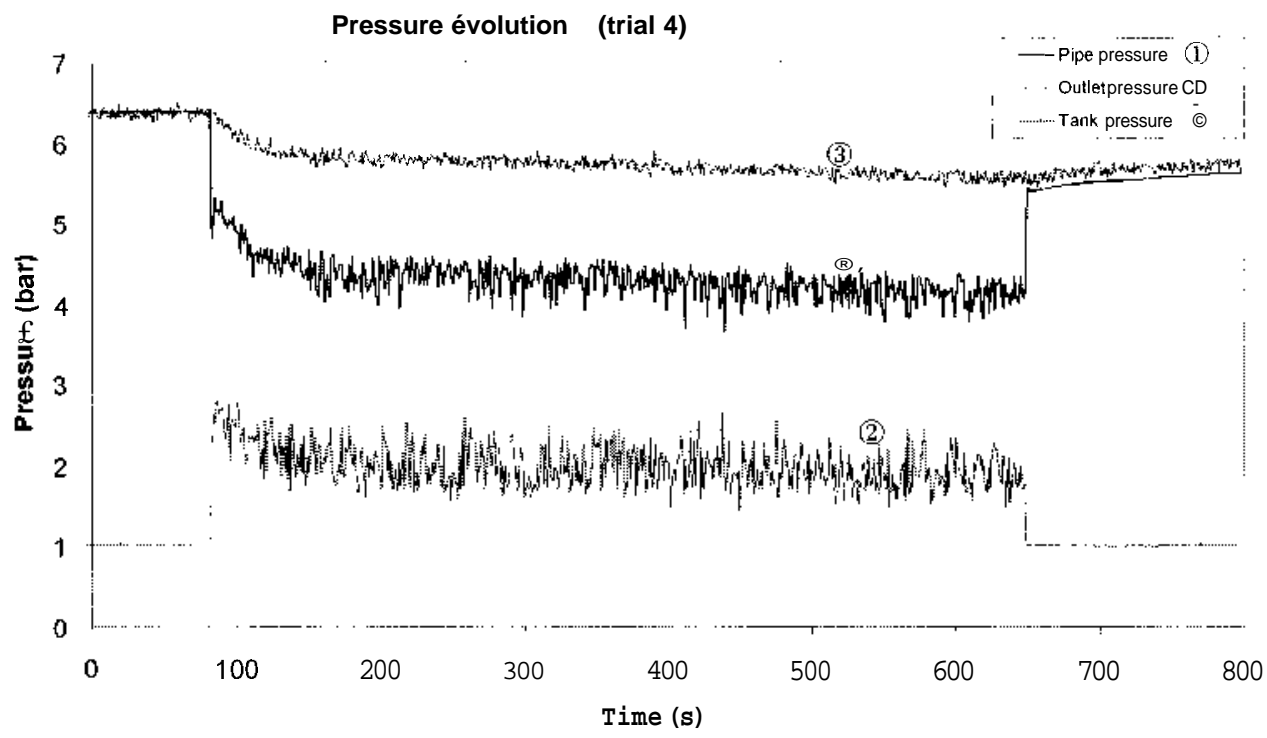

Figure 4 : Pressure evolution in the tank and in the pipe 


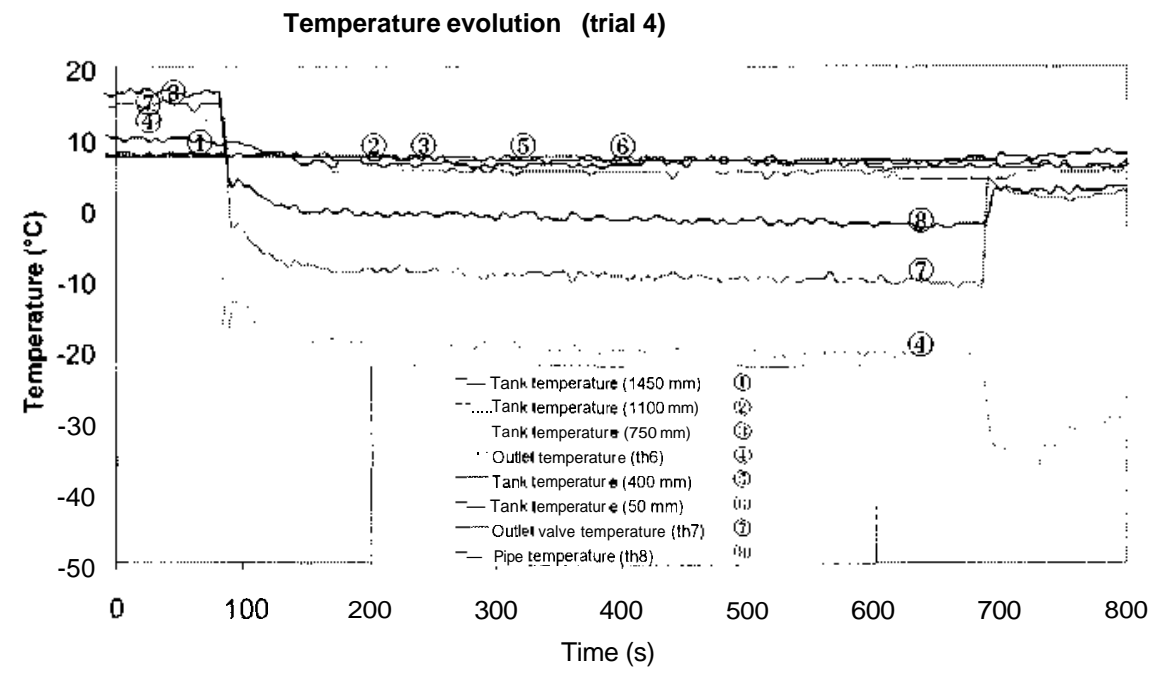

Figure 5 : Temperature evolution in the tank and in the pipe 


\begin{tabular}{|c|c|c|c|c|c|}
\hline $\mathrm{n}^{\circ}$ & $\begin{array}{c}\text { Duration } \\
(\mathrm{s})\end{array}$ & $\begin{array}{c}Q_{\text {released }} \\
(\mathrm{kg})\end{array}$ & $\begin{array}{l}\text { Flow } \\
(\mathrm{kg} / \mathrm{s})\end{array}$ & Configuration & Remarks \\
\hline 1 & 460 & 300 & 0.65 & 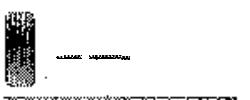 & Horizontal release in gaseous phase \\
\hline 2 & 440 & 1,980 & 4.5 & - & $\begin{array}{l}\text { Horizontal release in liquid phase } \\
\text { through an opening of } 20 \mathrm{~mm} \text { diameter }\end{array}$ \\
\hline 3 & 540 & 1,400 & 2.6 & 鼣, & $\begin{array}{l}\text { Release through a flange of } 2 \text { inches. } \\
\text { The distance between the two elements } \\
\text { of the support is } 1.6 \mathrm{~mm} \text { so that the } \\
\text { orifice surface of release is equivalent to } \\
18 \mathrm{~mm} \text { diameter }\end{array}$ \\
\hline $4 p$ & 660 & 2,380 & 3.6 & $L^{.10 \mathrm{~mm}}$ & $\begin{array}{l}\text { Horizontal release through one orifice of } \\
30 \mathrm{~mm} \text { diameter }\end{array}$ \\
\hline 4 & 600 & 2,520 & 4.2 & & $\begin{array}{l}\text { Horizontal release. } \\
\text { Reference case. }\end{array}$ \\
\hline 5 & 600 & 2,520 & 4.2 & & $\begin{array}{l}\text { Horizontal release impacting a wall of } \\
\text { surface } 3 \mathrm{~m} \times 3 \mathrm{~m} \text {. This wall is located at } \\
3 \mathrm{~m} \text { from the release point. }\end{array}$ \\
\hline 6 & 600 & 2,520 & 4.2 & end & $\begin{array}{l}\text { Horizontal release impacting a wall of } \\
\text { surface } 3 \mathrm{~m} \times 3 \mathrm{~m} \text {. This wall is located at } \\
1 \mathrm{~m} \text { from the release point. }\end{array}$ \\
\hline 7 & 670 & 2,560 & 3.8 & 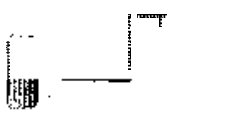 & $\begin{array}{l}\text { Vertical release impacting the ground } \\
\text { starting from a height of } 3 \mathrm{~m}\end{array}$ \\
\hline 8 & 875 & 3,420 & 3.9 & - & $\begin{array}{l}\text { Vertical release impacting the ground } \\
\text { starting from a height of } 1 \mathrm{~m}\end{array}$ \\
\hline 9 & 605 & 2,370 & 3.9 & $\mathrm{~T}_{1}$ & $\begin{array}{l}\text { Vertical release impacting the ground } \\
\text { starting from a height of } 1 \mathrm{~m} \text { in a } \\
\text { retention dike of } 2 \mathrm{~m} \times 2 \mathrm{~m} \text { of surface } \\
\text { and } 1 \mathrm{~m} \text { height }\left(4 \mathrm{~m}^{3}\right)\end{array}$ \\
\hline
\end{tabular}




\begin{tabular}{|c|c|c|c|c|c|}
\hline $\mathrm{n}^{\circ}$ & $\begin{array}{l}\text { Duration } \\
(\mathrm{s})\end{array}$ & $\begin{array}{l}\mathrm{V}_{\text {released }} \\
(\mathrm{kg})\end{array}$ & $\begin{array}{l}\text { Flow } \\
(\mathrm{kg} / \mathrm{s})\end{array}$ & Configuration & Remarks \\
\hline 10 & 690 & 2,150 & 3.1 & 许 & $\begin{array}{l}\text { Release identical to the release } n^{\circ} 4 \text { with } \\
\text { a water curtain located at } 25 \mathrm{~m} \text { of the } \\
\text { outlet (started in the course of test) }\end{array}$ \\
\hline 11 & 600 & 1,800 & 3 & & $\begin{array}{l}\text { Release identical to the release } \mathrm{n}^{\circ} 4 \text { with } \\
\text { a water curtain located at } 60 \mathrm{~m} \text { of the } \\
\text { outlet (started in the course of test) }\end{array}$ \\
\hline 12 & 660 & 2,000 & 3 & - & $\begin{array}{l}\text { Release identical to the } \mathrm{n}^{\circ} 4 \text {. The } \\
\text { temperature of liquid ammonia inside the } \\
\text { tank was lowered to }-12^{\circ} \mathrm{C} \text { before the } \\
\text { test. }\end{array}$ \\
\hline $2 b$ & 720 & 1,400 & 1.95 & $\prod^{17}$ & $\begin{array}{l}\text { Release identical to the } \mathrm{n}^{\circ} 2 \text { with an } \\
\text { opening of } 18 \mathrm{~mm} \text { diameter. }\end{array}$ \\
\hline $8 b$ & 780 & 2,120 & 2.7 & -1 & $\begin{array}{l}\text { Vertical release impacting the ground } \\
\text { starting from a height of } 1 \mathrm{~m} \text { in a } \\
\text { retention dike of } 10 \mathrm{~m} \times 10 \mathrm{~m} \text { of surface } \\
\text { and } 5 \mathrm{~cm} \text { height }\left(5 \mathrm{~m}^{3}\right) .\end{array}$ \\
\hline
\end{tabular}

Table 1 : Characteristics of the 15 configurations tested in the project 


\begin{tabular}{|c|c|c|c|c|c|c|}
\hline Tests n' & $\begin{array}{c}\text { Température } \\
\text { under shelter }\end{array}$ & $\begin{array}{c}\text { Relative } \\
\text { humidity }\end{array}$ & $\begin{array}{c}\text { Solar flux } \\
\left(\mathrm{kW} / \mathrm{m}^{2}\right)\end{array}$ & $\begin{array}{c}\text { Speed of the wind } \\
\text { at } 7 \mathrm{~m} \text { height }\end{array}$ & $\begin{array}{c}\text { Stability class } \\
\text { (determination of } \\
\text { standard deviations } \\
\text { of wind direction) }\end{array}$ & $\begin{array}{c}\text { Stability class } \\
\text { (determination of } \\
\text { Monin-Obukhov } \\
\text { length) }\end{array}$ \\
\hline 1 & $14^{\circ} \mathrm{C}$ & $76 \%$ & 0.2 & $5 \mathrm{~m} / \mathrm{s}$ & $\mathrm{D}$ & - \\
\hline 2 & $8.5^{\circ} \mathrm{C}$ & $84 \%$ & 0.1 & $3 \mathrm{~m} / \mathrm{s}$ & $\mathrm{D}$ & $\mathrm{C} / \mathrm{D}$ \\
\hline 3 & $5^{\circ} \mathrm{C}$ & $90 \%$ & 0.04 & $2.5 \mathrm{~m} / \mathrm{s}$ & $\mathrm{C}$ & $\mathrm{D}$ \\
\hline $4 \mathrm{p}$ & $10^{\circ} \mathrm{C}$ & $61 \%$ & 0.5 & $3 \mathrm{~m} / \mathrm{s}$ & $\mathrm{C}$ & - \\
\hline 4 & $12.5^{\circ} \mathrm{C}$ & $82 \%$ & 0.25 & $3 \mathrm{~m} / \mathrm{s}$ & $\mathrm{C}$ & $\mathrm{D}$ \\
\hline 5 & $20^{\circ} \mathrm{C}$ & $50 \%$ & 0.65 & $3.5 \mathrm{~m} / \mathrm{s}$ & $\mathrm{A}$ & $\mathrm{B}$ \\
\hline 6 & $12^{\circ} \mathrm{C}$ & $75 \%$ & 0.5 & $5 \mathrm{~m} / \mathrm{s}$ & $\mathrm{D}$ & $\mathrm{D}$ \\
\hline 7 & $13^{\circ} \mathrm{C}$ & $60 \%$ & 0.7 & $6 \mathrm{~m} / \mathrm{s}$ & $\mathrm{C}$ & $\mathrm{C} / \mathrm{D}$ \\
\hline 8 & $20^{\circ} \mathrm{C}$ & $37 \%$ & 0.7 & $5 \mathrm{~m} / \mathrm{s}$ & $\mathrm{D}$ & $\mathrm{C}$ \\
\hline 9 & $14^{\circ} \mathrm{C}$ & $50 \%$ & 1.0 & $3 \mathrm{~m} / \mathrm{s}$ & $\mathrm{A}$ & $\mathrm{B} / \mathrm{C}$ \\
\hline 10 & $24^{\circ} \mathrm{C}$ & $20 \%$ & 1.0 & $3 \mathrm{~m} / \mathrm{s}$ & $\mathrm{A}$ & A/B \\
\hline 11 & $24^{\circ} \mathrm{C}$ & $24 \%$ & 0.7 & $5 \mathrm{~m} / \mathrm{s}$ & $\mathrm{C}$ & $\mathrm{C}$ \\
\hline 12 & $15^{\circ} \mathrm{C}$ & $33 \%$ & 0.6 & $6 \mathrm{~m} / \mathrm{s}$ & $\mathrm{D}$ & $\mathrm{C} / \mathrm{D}$ \\
\hline $2 \mathrm{~b}$ & $18^{\circ} \mathrm{C}$ & $31 \%$ & 0.7 & $4 \mathrm{~m} / \mathrm{s}$ & $\mathrm{A}$ & A/B \\
\hline $8 \mathrm{~b}$ & $18^{\circ} \mathrm{C}$ & $31 \%$ & 0.6 & $5 \mathrm{~m} / \mathrm{s}$ & $\mathrm{C}$ & B/C \\
\hline
\end{tabular}

Table 2 : Average atmospheric conditions recorded during each trial 


\begin{tabular}{|c|c|c|c|c|c|c|}
\hline \multirow{2}{*}{ test $n^{\circ}$} & \multicolumn{6}{|c|}{ Distance from point of release } \\
\cline { 2 - 7 } & $20 \mathrm{~m}$ & $50 \mathrm{~m}$ & $100 \mathrm{~m}$ & $200 \mathrm{~m}$ & $500 \mathrm{~m}$ & $800 \mathrm{~m}$ \\
\hline \hline 1 & 15000 & 4500 & 1500 & 400 & 40 & 10 \\
\hline 2 & 55000 & 31000 & 20000 & 9000 & 900 & 300 \\
\hline $2 \mathrm{~b}$ & 33000 & 18000 & 6600 & 1600 & 60 & 20 \\
\hline 3 & 33000 & 20000 & 8000 & 2700 & 250 & 100 \\
\hline 4 & 65000 & 27000 & 16000 & 10000 & 1200 & 500 \\
\hline 5 & 28000 & 14000 & 6500 & 1500 & 140 & 30 \\
\hline 6 & 28000 & 13000 & 7300 & 2500 & 450 & 150 \\
\hline 7 & 25000 & 11000 & 5300 & 1000 & 160 & 60 \\
\hline 8 & 26000 & 12000 & - & - & - & - \\
\hline $8 \mathrm{~b}$ & 20000 & 8500 & 4000 & 800 & 70 & 30 \\
\hline 9 & 20000 & 5000 & 2000 & 450 & 30 & 5 \\
\hline 10 & 65000 & 29000 & 18000 & 4000 & 80 & 20 \\
\hline 11 & 65000 & 27000 & 15000 & 3500 & 300 & 80 \\
\hline 12 & 60000 & 20000 & 7000 & 1500 & 120 & - \\
\hline$-4 \mathrm{vanyyyy}$
\end{tabular}

-: value of concentration on the axis of the plume not measured

Table 3 : Average concentrations in ppm measured $1 \mathrm{~m}$ from height on the axis of the release 